\title{
Green Bonds vs Regular Bonds: Debt Level and Corporate Performance
}

\author{
Vitalii Chechulin \\ Financial analyst \\ $\underline{\text { ORCID }}$ \\ E-mail: vitalii.chechulin@ru.ey.com
}

EY Valuation and Advisory Services LLC, Moscow, Russia

\section{Elettra Agliardi}

M. Phil, PhD in Economics, Full Professor at the Department of Economics

$\underline{\text { ORCID }}$

E-mail: elettra.agliardi@unibo.it

University of Bologna, Italy

Journal of Corporate Finance Research, Vol. 14, No. 2, pp. 83-99 (2020)

DOI: https://doi.org/10.17323/j.jcfr.2073-0438.14.2.2020.83-99

Received 29 January 2020 ｜ Peer-reviewed 20 February 2020 ～Accepted 15 April 2020 


\section{Green Bonds vs Regular Bonds: Debt Level and Corporate Performance}

\section{Abstract}

This paper compares the effectiveness of traditional and green bonds for corporate performance among global companies which issue these types of bonds. Our research represents a first attempt to provide an original empirical contribution with a specific focus on the influence of green debt levels on corporate performance. We develop a framework for the analysis of the influence of the debt level on corporate performance, and also compare the influence of various types of bonds issuance on several indicators of corporate performance.

Our data refer to 118 companies from various industries and countries, including 17 companies issuing green bonds in the period from 2013 to 2017. We study the impact of debt levels on some standard corporate performance indicators, such as ROA, ROE, Revenue/Assets, EBITDA/Assets and EBIT/Assets.

Our results show that bond issuance has a positive effect on corporate performance. In particular, the relationship between debt levels and corporate performance is described in a non-linear way (an inverse U-shape), i.e., as debt level increases, the firm's corporate performance grows, but only up to a certain point where the largest positive effect is achieved. Moreover, we find that the issuance of green bonds has a larger positive impact on corporate efficiency than traditional bonds and the growth in the share of green financing in the total company's debt has a positive impact on corporate performance.

This study opens up avenues for further research in the field, and combining our approach to evaluating the effect of green bonds on corporate performance with an examination of companies arranged according to their life cycle stage would be intriguing. However, at the present stage of development of the green bonds market it is impossible to study their influence on corporate performance as the research selection is rather small, and this market has emerged rather recently.

Key words: green bonds, corporate performance, debt level, multi-regressions

JEL classification: G3, C3, C5, F01, F21, F63 Y1, Y3, Y4 


\section{Introduction}

The last decade showed several signs of raised awareness in many areas of the financial system of effective mobilisation of capital in green activities. One of the reasons for this is increased global awareness and the interest of executives and investors in preserving the environment and following ESG principles. Green and sustainable finance can play an essential role in reducing carbon emissions, developing resilient climate infrastructure, and improving environmental sustainability, all of which contributes to achieving parts of the UN's sustainable goals for 2030 [1] Subsequent to 2015, after the signing of the Paris climate agreement, the green bonds market developed rapidly. In 2019, approximately 250 billion US dollars' worth of green bonds were placed. This accounts for $25 \%$ of the total global amount of green bonds issued since their first issuance. The most developed green bonds market is in the USA, representing the largest amount of issuances (including the likes of Apple, Amazon, Fannie Mae, etc.). Emerging markets also started indicate investors' concerns vis-à-vis the preservation of the environment through, for example, reductions in carbon emissions. In the Russian emerging market, the first green bonds were issued in 2018 by government-owned companies. Larger private Russian companies may follow their lead.

The objective of this paper is to study the impact of green bond financing on corporate performance. One of the indicators which influences corporate performance is the debt load. Here we will examine both green debt and straight (or regular) debt, in order to ascertain whether green bonds financing has a different impact on corporate performance. Defining the capital structure, including debt financing, plays an essential role in the analysis of corporate sustainable growth. By raising borrowed funds, companies may invest in expansion of production facilities, but by increasing the debt load companies run a heightened bankruptcy risk.

Our paper studies green bonds, which are a new financing method in terms of general Russian practice. Consequently, our work will be also interesting for Russian practice in studying the effectiveness of green bonds on corporate performance. Green bonds may be an effective means for raising loan financing. On one side, the ecological situation in the world requires more serious financing by corporations to preserve the environment. On the other hand, emerging countries grow quicker on account of industrial production, which is detrimental for the global environment. However, in the scientific literature, the amount of work studying a comparison of the influence of straight and green bonds on corporate performance is still limited, and the results obtained so far are controversial.

The novelty of our study is as follows. This research represents a first attempt to provide an original empirical contribution with a specific focus on the influence of green debt levels on corporate performance. We develop a framework for the theoretical aspects of straight bonds and green bonds, analyse approaches for assessment of the influence of the debt level on corporate performance, and also compare the influence of various types of bonds issuance on several indicators of corporate performance. The purpose of our research is to evaluate whether green bonds have a more positive impact on corporate performance than regular bonds.

This paper is organised as follows. Section 2 describes some characteristics and trends of the green bonds market. In Section 3, we present a review of the relevant literature on capital structure, uncover the principal trends in defining the level of debt load of a company, and consider the factors which influence the level of corporate debt in various economic sectors. We study the governing motives of a change of debt level and analyse the factors which define its size. Section 4 presents the regression models we use to evaluate the influence of the debt level, including green debt, on corporate performance and discusses the methodology of our research. Section 5 analyses the suggested research hypotheses and discusses our empirical results. Finally, Section 6 concludes our study.

\section{The Green Bonds Market: Global Trends}

Green bonds are debt securities with the same characteristics as other bonds, whose distinctive feature relates to the fact that the purpose of green bonds is to raise funds to finance projects related to preservation/improvement of the environment. Apart from researchers in the economics of climate change and business practice, PwC (2019) make the point that it is insufficient for a business to only be focused on being profitable and lavish in paying dividends [2]. A business's social and environmental responsibility gains ever-greater significance when evaluating investment attractiveness. The development of the global green bond market is conditioned by understanding and gaining awareness of risks related to the state of the environment, the efforts of businesses (especially larger ones) to be socially responsible, and follow principles related to Environmental Social Governance (ESG).

Thus, the green bonds market continues to develop rapidly. The majority of top companies - industrial leaders (e.g. Apple, Amazon, Saudi Aramco etc.) adhere to ESG principles, and also invest in projects of environment maintenance, and disclose detailed information on sustainable development on official websites.

According to the research by PwC (2019) the capital involved in environmentally responsible investing incremented by one third biennially from 2014 to 2018 . Also, out of 2,000 scientific studies conducted since the1970s, $63 \%$ showed a positive correlation between ESG and a higher value of a public company [2]. Those bonds which may be included in the green bonds sector should comply with International Capital Market Association (ICMA) principles, and the green bonds standards of the international non-profit organisation Climate Bonds Initiative (CBI) [3]. These standards provide an extensive 
taxonomy and certification for green bonds. Currently, a few EU Member States have labelling schemes in place. These schemes build on different taxonomies and classify environmentally sustainable economic activities. A recent EU taxonomy listed the objectives that green funding should accomplish, being climate change mitigation, climate change adaptation, sustainable use and protection of water and marine resources, transition to a circular economy, pollution prevention and control, and protection and restoration of biodiversity and ecosystems (EU, 2019).

The first green bond was issued in 2007 by the European Investment Bank. The funds gained by placement were used to finance projects of renewable energy and energy efficiency.

Since 2013, a significant growth of the green bonds market has taken place when companies and sovereign borrowers entered the green bonds market. Morgan Stanley named this evolution the 'green bond boom' According to the Financial Times magazine in March of

Figure 1. Top 5 countries issuing green bonds in 2019

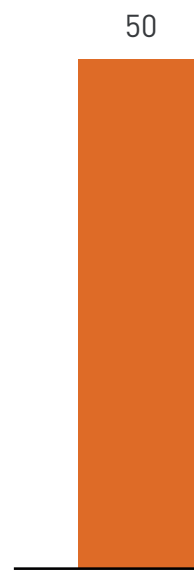

31

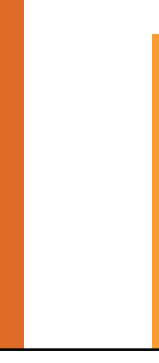

US

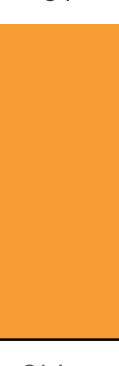

China

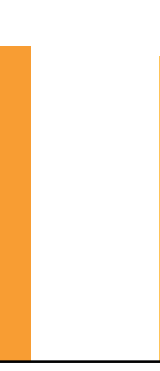

Source: Capital IQ database, author's own calculations.

As reported by CBI, in 2019 the largest sectors which issued green bonds were the power industry (31\% of the green market), construction $-30 \%$, and transport $20 \%$.

In the American green bonds market the largest issuer is Fannie Mae, involved in mortgage securitisation. In 2019 its share in the total portfolio of green bonds amounted to $9 \%$ (22.9 billion US dollars). In Russia, according to the report by the Bank of Russia (2018) the first issue of green bonds was made in December 2018 by Resursosberezheniye KHMAO LLC (which is a member of a group of companies engaged in solid municipal waste management JSC Upravleniye Otkhodamy) which amounted to 1.1 billion rubles. The second issue was made in May 2019 by RZhD and amounted to 0.5 billion Euro. At the moment, there are no other issues of green bonds in Russia. The Russian green bonds market is just emerging and forms a still meagre share of the global green bonds market.
2014, Unilever issued green bonds worth of 250 billion pounds in order to reduce waste and gas emissions in their plants. As per The Guardian, in February 2016 Apple issued these kind of bonds, worth 1.25 billion US dollars, in order to finance more power-efficient installations of system heating and cooling and the use of biodegradable materials by the company. In accordance with the data of the non-profit organisation Climate Bonds Initiatives (CBI, 2019) between the years 2007 and 2019 green bonds worth 771 billion US dollars were placed in total, and in 2019 approximately 250 billion US dollars worth were placed [4]. This exceeds by $51 \%$ the amount placed within a similar period for the previous year. According to the Bank for International Settlements, in comparison to the general bonds market, green projects amount to $0.6-1.3 \%$ of the global market [4].

In Figure 1 the largest countries issuers of green bonds in 2019 are shown. The main issuers of these bonds are the developed economies, such as USA, France, Germany, the Netherlands, and China.
19

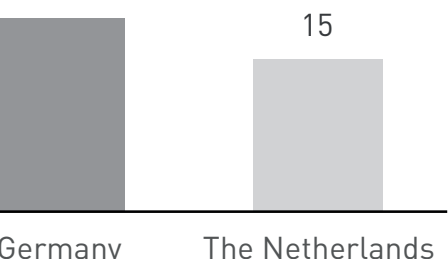

\section{Debt level and Corporate Performance: a review of the literature}

The debt load is directly related to the notion of capital structure. The majority of existing scientific research is based upon the Modigliani-Miller theorem on the independence of capital structure when defining the company value in the circumstances of a perfect capital market, (absent transaction and agency costs).

By using debt financing, the companies obtain advantages which are expressed by the existence of the tax shield (Modigliani - Miller), minimisation of the agency problem between managers and owners [5], and the transfer of positive signals as regards company performance because managers have inside information on the future performance of the company [6]. However, use of debt may also result in the bankruptcy of enterprises. On the other 
hand, use of debt may reduce agency costs related to free cash flow, proceeding from the premise that managers tend to observe discipline, take reasonable investment decisions, and not prioritise personal benefits before the interests of the company [7]. The high profitability of a business sends creditors positive signals regarding future cash flows which, in turn, reduces the cost of the debt capital and increases corporate performance. However, in practice, such premises do not always come about. The capital market is not unfailingly efficient and an economic operator may act unreasonably.

In the next subsections we discuss the literature that dealt with interrelations between debt level, green bonds, and corporate performance.

\section{Influence of Debt Level Including Green Bonds on Corporate Performance}

Traditionally, corporate performance has been described in relation to return on assets (ROA). On the one hand, in the paper [8], the interrelation of financial leverage and corporate performance (ROA) was studied using a large selection of Chinese companies. Lev (financial leverage), size (company size), growth and profit (company revenue) were used as independent variables. The paper found that $86 \%$ of companies have short-term debt, and the hypothesis of a positive influence of the level of debt load on corporate performance was confirmed. In the paper [9] concerning the influence of debt level on a company's operations, public companies from Ghana were studied. Return on equity (ROE) was used as an indicator of corporate performance, and financial leverage, the revenue logarithm, and revenue growth were used as variables. The empirical analysis found out that corporate performance in the companies where short-term debt prevails is higher than in companies with a significant long-term debt load. Generally, testing also identified a positive relation between the debt load level and corporate performance.

On the other hand, in the paper [10], a non-linear interrelation between the debt load level and efficiency of companies' operation was shown. Debt financing and corporate performance indicators are bound by U-shaped relations to the decisive figure of $56.36 \%$. Consequently, when the debt level is $56 \%$, the corporate performance of a company achieves the largest amount.

So, the debt level, as referred to in the majority of contributions, has a positive impact on corporate performance. Even though a growing number of research papers deal with the issuance of green bonds, there are very few which provide a comparison of green bonds and straight bonds on corporate performance.

New investment terms set a trend among business experts for corporate social responsibility (CSR). It is a method used by companies to comply with the principles of sustainable development. One of the means of implementation of such principles is the issue of green bonds. In the paper [11], three main reasons for issuing these kind of bonds were distinguished. First, green bonds may be an indicator of the company's commitment to environmental maintenance (known as the signal argument). This argument may attract investors because in some cases companies disclose the obligations of environmental care insufficiently when the company has such a concern. Second, a green bonds issue may be a kind of "green advertising of bonds" (greenwashing). Greenwashing represents often unfounded and misleading declarations made by corporate management concerning obligations around environmental preservation. In such cases, companies offer issues of green bonds, describing themselves as ecologically responsible corporations, but they take no actual measures (known as the greenwashing argument). Third, companies may issue green bonds in order to obtain a cheaper financing from investors (known as the cost of capital argument). Analysis of 565 green bonds issued by 225 companies revealed that the most relevant motive for issue of the new type of bonds, in the opinion of Flammer, is the signal argument in particular. Large cash flows and prospects may be shown through debt increase.

It is argued that this type of green debt funding may be more profitable than equity financing for several reasons, such as:

- Advantages of the tax shield.

- Smaller expenses for raising debt funding than for equity financing.

- $\quad$ Retaining control of the company.

- Less strict regulatory requirements and information disclosure.

It should be noted that research devoted to CSR started long before the corporate management realised the advantages of this approach. For a long time it was thought that investments in environmental preservation initiatives could provide economic benefits only in extraordinary circumstances. However, global companies' strive for reduction of emissions in the environment provides a more stable financial position in the market for such initiatives. Prevention of industrial pollution helps companies to liquidate environment-damaging procedures, readjust manufacturing processes, and cut down the corporate expenses for manufacturing [12]. It is important to notice that the abatement of environmental pollution may increase the demand for ecologically-responsive customers for certain related goods [13-15]. As shown in the paper [16], liquidity in the green bonds market is higher than in the straight bonds market. This confers an advantage to issuers in raising large funds. Usually the investors' demand exceeds supply and green bonds are traded with a negative premium to straight bonds $[17 ; 18]$.

However, M. Jensen [5] and I. Strebulaev [19] have a contrary opinion as regards the influence of debt level on corporate performance. Their papers show that the relation between debt and companies' profitability is more complex and may be negative. For example, when the debt load increases during periods of hostile takeovers (or during periods of defending against them) a company incurs 
huge agency costs. In these cases, the financial leverage is so large that a company cannot operate in its conventional form and earn profit.

S.C. Myers and N.S. Majluf [20] developed a pecking order theory, according to which undistributed profit (categorically known as an 'internal' source) prevails among the financing sources, followed by debt capital, and convertible bonds are the remaining source. Additional issue of shares is used as a last resort, because the market considers it as a negative signal. In accordance with the research [21], expenses for issue of debt obligations in US markets amounted to approximately $1 \%$ of the sum of raised funds, while similar expenses related to the issue of shares were in the range of 4 to $15 \%$. From the standpoint of the trade-off approach which implements that companies of a certain industry have similar capital structures, it remains unclear why companies with high profitability tend to choose a lower debt level. From the point of view of the pecking order theory, expenses of an adverse selection of investment projects may outbalance benefits, and therefore companies choose a certain hierarchy of financial instruments. Thus, highly-profitable companies do not need to attract other, less preferable financing sources.

A decision on the amount of debt often depends on the long-term strategy of the company's external borrowings. For example, it is shown in the papers $[22 ; 23]$ that large companies are financed more from external sources, and in the paper [24] it is indicated that growing companies also raise funds, since they lack proprietary funds and there is a great demand in the capital markets. These studies predict a negative relation between financial leverage and company performance efficiency. In the paper [25], 3,095 companies from Great Britain and the USA were studied in the period 2002-2004. A conclusion was made that business profitability has a negative relation with the possibility of and search for raising external financing. Consequently, in periods of high profitability, companies should use profits to satisfy corporate needs instead of issuing high risk securities.

When companies use debt financing, conflicts of interest between the stakeholders and debtholders may take place, and this results in agency costs. When the financial leverage level is high, managers acting on behalf of their stakeholders may refuse to accept the project with a positive net discounted value because a high-risk debt will replace and absorb a part of the stakeholders' benefits. In such a case, there is also a negative relation between the debt level and corporate performance. In countries with significant government participation in the capital of companies, the negative dynamics of financial leverage and company profitability are observed. In the paper [26] the first empirical research studies of 549 Chinese public companies traded in the Shanghai and Shenzhen stock exchanges were presented. The regression analysis showed that increasing the financial leverage is an ineffective method of cutting agency costs and, consequently, of increasing corporate performance. In the research [9] the interrelation between capital structure and performance efficiency of companies traded in the Ghana Stock Exchange over the period 1998-2002 was studied. A measure of corporate performance efficiency was ROE (return on equity), and independent variables were debt, revenue, debt/capital and revenue growth \%. Analysis revealed a negative relation between a long-term debt and return on equity. It should be noted that the influence of a shortterm debt on corporate performance was also studied in this paper. The relation between ROE and short-term debt was strongly positive, moreover, more profitable companies use more often the short-term debt to finance their operations ( $85 \%$ in the total debt amount).

\section{Influence of Green Bonds Issue on Corporate Performance}

A few researchers tend to believe that interrelations between the issue of green bonds and corporate performance is positive. S.L. Hart and G. Ahuja [12] found out that a reduction of pollutant emissions within one or two years since the beginning of a project may increase company profits. A.A. King and M.J. Lenox [27] studied 652 US manufacturing companies and rendered a conclusion regarding the positive dependence between environmental care and financial results. C. Lassala, A. Apetrei and J. Sapena [28] noted that there is a positive relation between the financial results of a company and green bonds issue. A selection of 84 companies, which comprised 38 socially responsible companies and 46 companies not involved in social responsibility, was used for their analysis. Their results showed that the return on equity (ROE) of socially responsible companies was higher, especially in the consumer services and technology sector. In the paper by I. Miroshnychenko, R. Barontini and F. Testa [29] the influence of green practice on corporate financial results using ROE and Tobin's $\mathrm{Q}$ as a proxy was examined. The selection consisted of 3,490 public companies from 58 countries and 19 economic sectors. Manufacturing (84.9\%) and transport (4.5\%) accounted for the major part of the total selection. They showed a positive interrelation between the use of green practices, and improvement of financial indicators of a companies' operations.

It should be noted that significant limitations of the above-mentioned results are due to the rather small availability of data, in terms of selecting companies and time lag of implementation of environmental preservation projects.

The authors of this literature display various attitudes towards the efficiency of green bonds. Some of them see a negative influence of green bonds on corporate operations, while others abstain from affirmations concerning the impact of this type of bond on corporate performance. In the paper [30] two selections of companies were tested: 1) companies which issued green bonds; and 2) companies which issued straight bonds. The final selection of companies with green bonds comprised 88 companies, mainly from Great Britain, USA, China, and Japan while the second selection comprised 140 companies. When evaluating the change of the companies' financial status, 
ROA was used as a variable and it was discovered that green bonds issuance had no impact on the improvement of companies' financial status. This conclusion may be explained by several reasons. In particular, although at issuance green bonds may potentially improve a company's performance, the market often requires more time for implementation.

Some conventional research studies also think that the ratio of corporate social performance (CSP) to financial performance (FP) is negative. Corporate interests should not be at variance with investors' interests. Achievement of social goals requires additional expenses and contradicts the common goal of profit maximisation. In the article by G. Van der Laan, H. Van Ees, and A. Witteloostuijn [31] the interrelation between social responsibility and financial performance was studied. They made the conclusion that the effect of a negative influence of social indicators on corporate financial performance is much stronger than the CPS's positive contribution to the financial status. For example, when customers' demand is not satisfied due to additional costs for social indicators, the return on assets (ROA) for an average company is reduced from 8 to $0 \%$.

Thus, there are different points of view about the influence of green bonds issue on corporate performance. It should be noted that in recent years the majority of research has served to disentangle indicators of a positive influence. This fact may be conditioned by the development of the green bonds market, and thus of a larger selection of data and studies.

On the basis of the literature we reviewed in Section 3, we present the following research hypotheses.

Hypothesis 1: There is a positive interrelation between issuance of bonds and corporate performance.

Hypothesis 1 is the fundamental one and is based on the assumption that the debt load of companies at the time of bonds issuance is less than the "happy mean" defined by the trade-off theory (otherwise the high probability of default would be included in the expenses of debt servicing). In other words, with such an approach, a company could consider borrowed funds financing as financially unviable. Alternatively, we present:

Hypothesis 2: There is a positive interrelation between debt level and corporate performance.

Moreover, regarding green bonds, we have:

Hypothesis 3: Green bonds issuance has a more positive effect on corporate performance than straight bonds.

Hypothesis 3.1: The growth of the share of green bonds in the amount of company debt has a positive impact on corporate performance.

\section{Methodology and Database}

Our analysis will be focused on some indicators of corporate financial performance for a certain period before and after bonds issuance. In our opinion, the full effect of bond issuance may be observed in at least two to three years after the bond issuance. This assumption is based on the fact that after a bond issuance, a company spends some time on resources for investments and achievement of the first results. The length of green bonds maturity is rather long and often not smaller than five years. Most likely, the life cycle for the green investment project has the same length.

To account for the time it takes for a full effect on corporate performance, we consider the following variations:

change of the company's financial performance indicators in the period not exceeding one year since the date of green bonds issuance, and after the expiry of two years; change of the company's financial performance indicators within one year since the date of green bonds issuance, and after the expiry of three years.

In accordance with the hypothesis above, the performance indicators should be higher when a longer period is considered (i.e. three years) because the average length of investment projects in the industries which issue green bonds exceeds two-three years in the majority of cases. However, in this analysis the possibility to study only a three-year period after a bond issuance is limited because the majority of bonds in our sample had been issued recently, and an increase of this window will result in a reduction of data availability. Furthermore, the study of the influence of green bonds issuance on corporate performance indicators is impossible without controlling for the selection of companies which did not issue green bonds within the considered period. Our objective consists in comparing changes of corporate financial performance from two selections:

in the first selection all companies issued green bonds; in the second selection all companies did not issue green bonds within the considered period.

A statistically significant difference in the change of performance indicators will be indicative of an impact of green bonds issuance on corporate financial performance. However, it should be noted that other factors also influence corporate financial indicators. Theoretically, failure to take these factors into consideration in the analysis may result in biased results. This is precisely why we will add other indicators which may have some influence on corporate performance.

\section{Regression Model Specification}

The basic specification of the regression model used in our research is as follows, as exemplified by Revenue/ Assets. Depending on the testing of the performance indicator, the following indicators are also selected: RoA, RoE, EBITDA/Assets, EBIT/Assets.

$$
\begin{aligned}
& \text { Revenue } / \text { Assets }_{\text {post }}-\text { Revenue } / \text { Assets }_{\text {pre }}= \\
& =\beta_{0}+\beta_{1}{ }^{*} \log (\text { Assets })+\beta_{2}{ }^{*} \text { Leverage }+ \\
& +\beta_{3}{ }^{*} \text { Leverage sq }+\beta_{4}{ }^{*} \mathrm{~d}(\text { Leverage })+\mathrm{e}
\end{aligned}
$$


The independent variables are: assets, describing company size (a modified version uses the asset value logarithm); leverage, as a measure of debt load (which is defined as total debt to market capitalisation); the square of financial leverage, to evaluate possible non-linearities; and the change in leverage.

Change of the value of financial leverage in the period of one year before a bond issuance (or absence of issuance for companies from the control selection) and two or three years subsequent to the date of issuance will also be indicative of the amount of the funds raised where $X$ is a corresponding financial indicator for green bonds, and we are interested in understanding how this should influence corporate financial performance. However, we cannot assert with confidence how a change of the financial leverage should influence the company financial performance because the result depends on the amount of the financial leverage before the issue (lesser or more than the "happy mean" defined by the trade-off theory).

We will use the following specification of regression models $1-5$ in order to verify hypothesis 1 :

$$
\begin{aligned}
& X_{\text {post }}-X_{\text {pre }}=\beta_{0}+\beta_{1} * \log (\text { Assets })+ \\
& +\beta_{2} * d(\text { Leverage })+\beta_{3} * \text { Sector } O \& G+ \\
& +\beta_{4} * \text { CountryUSA }+\beta_{5} * \text { Bond issue }+e
\end{aligned}
$$

where $X$ - a corresponding financial indicator;

The dummy variable CountryUSA was used as the largest country-issuer of green bonds worldwide.

In order to verify hypothesis 2 we add the square of the financial leverage for the following specification of regression models:

$$
\begin{aligned}
& X_{\text {post }}-X_{\text {pre }}=\beta_{0}+\beta_{1} * \log (\text { Assets })+ \\
& +\beta_{2} * d(\text { Leverage })+\beta_{3} * \text { Sector O \& } G+ \\
& +\beta_{4} * \text { CountryUSA }+\beta_{5} * \text { Leverage }+ \\
& +\beta_{6} * \text { Leverages }+\beta_{7} * \text { Bond issue }+e
\end{aligned}
$$

In order to verify hypothesis 3 and 3.1 we use the following specification of regression models $1-5$, taking into account green bonds issues:

$$
\begin{aligned}
& X_{\text {post }}-X_{\text {pre }}=\beta_{0}+\beta_{1} * \log (\text { Assets })+ \\
& +\beta_{2} * d(\text { Leverage })+\beta_{3} * \text { Sector O \& } G+ \\
& +\beta_{4} * \text { CountryUSA }+\beta_{5} * \text { Leverage }+ \\
& +\beta_{6} * \text { Leverage } q+\beta_{7} * \text { Bond issue }+ \\
& +\beta_{8} * \text { Green Bond }+\beta_{9} * \text { GB } / \text { Debt }+e
\end{aligned}
$$

Here, Green Bond is a dummy variable which takes a value of 1 if the issued bond is green and 0 otherwise, while $G B / D e b t$ is the share of green bonds out of total debt at issuance. GB/Debt share change is defined after 2 and 3 years after issuance. Green bonds issuance is getting more popular so the growth of $G B$ share in total debt portfolio is also increasing after 2 and 3 years since bonds issues.

\begin{tabular}{|c|c|c|c|c|c|}
\hline Country & $\#$ & $\%$ & Country & $\#$ & $\%$ \\
\hline Sweden & 4 & 24 & Italy & 1 & 6 \\
\hline Norway & 3 & 18 & India & 1 & 6 \\
\hline USA & 2 & 12 & Denmark & 1 & 6 \\
\hline Canada & 1 & 6 & Great Britain & 1 & 6 \\
\hline France & 1 & 6 & Colombia & 1 & 6 \\
\hline Argentina & 1 & 6 & & & \\
\hline
\end{tabular}

\section{Data Selection}

Table 1 shows the distribution of our data on 118 companies from various industries and countries including 17 companies issuers of green bonds. The most representative selection is the one for bond issuers from the USA (63\% of all studied companies) and Europe (33\%). First of all, it is related to a high level of development of capital markets in the above regions. It should be noted that the leaders as regards the amount of green bonds issues are Sweden, Norway, and USA (54\% of the total selection).

Table 1. Distribution of the chosen companies issuers of green bonds by countries

Source: Capital IQ, author's own calculations.

Table 2. Descriptive statistics of the main financial data of companies, in billions of US dollars (unless indicated otherwise)

\begin{tabular}{cccccc} 
& Assets & Revenue & EBITDA & EBIT & Financial leverage, \% \\
Min & 0.0 & 0.0 & -2.0 & -12.5 & 0 \\
\hdashline Median & 18.2 & 7.8 & 1.8 & 1.2 & 80
\end{tabular}




\begin{tabular}{|c|c|c|c|c|c|}
\hline & Assets & Revenue & EBITDA & EBIT & Financial leverage, \% \\
\hline Average & 62.0 & 22.4 & 5.0 & 3.5 & 131 \\
\hline \multirow[t]{2}{*}{$\operatorname{Max}$} & $1,893.8$ & 433.5 & 82.5 & 71.2 & 2,811 \\
\hline & RoA & RoE & Revenue/ Assets & $\begin{array}{l}\text { EBITDA/ } \\
\text { Assets }\end{array}$ & EBIT/ Assets \\
\hline Min & -82.5 & -99.0 & 0.0 & -46.0 & -47.1 \\
\hline Median & 3.2 & 9.6 & 40.3 & 9.1 & 5.7 \\
\hline Average & 3.1 & 10.8 & 47.6 & 10.7 & 6.9 \\
\hline Max & 79.4 & 301.0 & 199.0 & 168.1 & 50.6 \\
\hline
\end{tabular}

Source: Capital IQ, author's own calculations.

It should also be noted that approximately $50 \%$ of all considered companies are from extractive or manufacturing sectors of economy, both of which have a significant pernicious effect on the environment. Besides this, the majority of green bonds included in the selection (approximately $65 \%$ ) were issued by companies from these economic sectors, and this supports the hypothesis on companies' commitment to environmental preservation.

Such descriptive statistics of the main financial data collected from companies' reports are indicated in Tables $2-3$. It should be also noted that the average financial leverage of the companies in the selection is $131 \%$. It is indicative of such companies' inclination to finance their activity more using borrowed funds, rather than their stakeholders' funds.

\section{Descriptive Statistics of the Chosen Companies}

Let us consider in detail the descriptive statistics of corporate performance indicators. The following financial indicators are characteristic of an average company from the selection: RoA amounts to $3.1 \%$; RoE to $10.8 \%$. This means that such company needs approximately nine or ten years to fully achieve the full cost of recovery of invested funds, provided the net profit dynamics within the above period is steady. Moreover, one can make the conclusion on the basis of the data below that the net profit margin of an average company within the period of 2011 to 2019 varied in the range of $6-7 \%$.
A study of descriptive statistics of financial indicators, without taking into consideration the time factor, may result in a loss of some additional information, namely, the nature of the dynamics of indicators between 20112019. Appendix 1 illustrates distribution of performance indicators' values from 2008 to 2019. Green marks in the diagram show average values by years, and purple and red marks show maximum and minimum values, respectively. One important conclusion is the relative stability of average values of almost all performance indicators. RoA and $\mathrm{RoE}$ are the exception. A special feature of their dynamics is the achievement of maximum values in 2009-2010 and 2018-2019.

On the contrary, in the period of 2015-2017, RoA and RoE values achieved their local minimum. A study of the dynamics of EBIT/Assets made on the basis of use of profit before taxes and interest paid for loans is indicative of an absence of strongly pronounced trends in dynamics, unlike with RoA and RoE. The difference in dynamics may be explained by changes in tax policy in the USA after Donald Trump was elected president in 2016 (tax remissions for corporations were implemented in 2017-2019), and by the interest rate reduction by the US Federal Reserve.

From the point of view of academic research, data concerning bonds issue are of primary interest. The total number of issues made by the companies we analyse in the period of 2013 to 2017 is 323, where 50 issues are green bonds.

Table 3. Descriptive statistics of the issued bonds characteristics

\begin{tabular}{llll} 
Green bonds & $\begin{array}{l}\text { Sum, million } \\
\text { US dollars }\end{array}$ & $\begin{array}{l}\text { Maturity period, } \\
\text { years }\end{array}$ & $\begin{array}{l}\text { Option adjusted spread, } \\
\text { bpts }\end{array}$ \\
Min & 3.0 & 2.0 & 21.5 \\
\hdashline Median & 120.0 & 5.0 & 74.4 \\
\hdashline Average & 339.0 & 5.9 & 107.8 \\
\hdashline Max & $2,000.0$ & 15.0 & 347.5
\end{tabular}




\begin{tabular}{llll} 
Green bonds & $\begin{array}{l}\text { Sum, million } \\
\text { US dollars }\end{array}$ & $\begin{array}{l}\text { Maturity period, } \\
\text { years }\end{array}$ & $\begin{array}{l}\text { Option adjusted spread, } \\
\text { bpts }\end{array}$ \\
Straight bonds & Sum, million US dollars & Maturity period, years & Option adjusted spread, bpts \\
\hdashline Min & 0.1 & 3.0 & 10.9 \\
\hdashline Median & 700.0 & 10.0 & 163.2
\end{tabular}

Source: Capital IQ, author's own calculations.

Figure 2. Dynamics of the number of bonds issues in the period of 2013 to 2017 by type

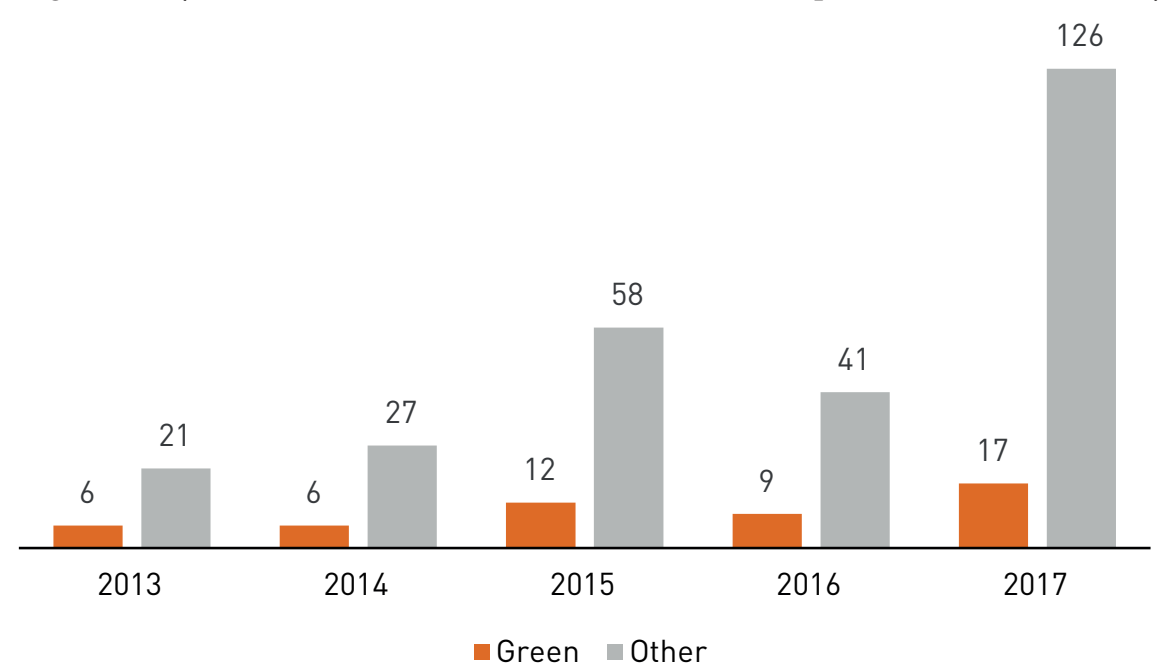

Source: Capital IQ, author's own calculations.

Table 3 states the descriptive statistics of the main characteristics of bonds issues. The fact that the average size of green bonds is significantly smaller than that of straight bonds - 339 million US dollars versus 843 million US dollars - is of interest. It should also be noted that the average maturity period of green bonds is virtually half that of straight bonds. This fact may support the hypothesis that companies use green bonds issues to finance investment projects with a lesser payback period and project implementation period.

It is also important that the average spread of green bonds yield to government bonds yield (OAS spread) is significantly less (by 120 basis points) than that of straight bonds. This implies that on average, investors evaluate the degree of credit risk for green bonds as smaller than for straight bonds (Figure 3).
Meanwhile, this result may be related to the fact that green bonds are issued by the companies with a rather high credit rating, and this impacts respectively the yield to maturity, (YTM). In order to verify both hypotheses it is necessary to conduct additional studies.

Speaking of the dynamics of the number of bonds issues, similar trends of both types are worth noting. Moreover, the virtually unchanged share of green bonds issues by years should be mentioned. This fact may be related to our selection of companies.

\section{Results of the Empirical Analysis}

Let us discuss the results of the regression analysis. In order to verify each hypothesis we considered five regression models. Let us start from hypothesis 1. 


\section{Results of verification of hypothesis 1}

Table 4. Verification of hypothesis 1 (one year before bonds issuance - two years after bonds issuance). Robust standard errors were used.

\begin{tabular}{|c|c|c|c|c|c|}
\hline $\begin{array}{l}\text { One year "before" - } \\
\text { two years "after" }\end{array}$ & $\begin{array}{l}\text { Revenue/ } \\
\text { Assets }\end{array}$ & $\begin{array}{l}\text { EBITDA/ } \\
\text { Assets }\end{array}$ & $\begin{array}{l}\text { EBIT/ } \\
\text { Assets }\end{array}$ & RoA & RoE \\
\hline Intercept & 0.022 & $0.19^{* *}$ & -0.033 & $0.22^{* * *}$ & $-0.21^{\star}$ \\
\hline Log(assets) & $-0.0071^{\star}$ & $-0.021^{\star \star \star}$ & 0.0007 & $-0.018^{\star \star \star}$ & $0.017^{\star}$ \\
\hline$\partial($ Leverage) & $-0.0007^{\star}$ & $-0.0005^{\star}$ & -0.0001 & $0.0001^{*}$ & $-0.0017^{\star * \star}$ \\
\hline Sector O\&G & $0.021^{\star}$ & $0.019^{*}$ & 0.015 & $0.009^{\star}$ & -0.005 \\
\hline Country USA & -0.003 & 0.001 & 0.002 & -0.005 & $-0.006^{\star}$ \\
\hline Bond issue & $0.046^{*}$ & $0.065^{\star * *}$ & $0.038^{*}$ & -0.041 & $0.14^{*}$ \\
\hline Adjusted R sq & 0.39 & 0.48 & 0.28 & 0.42 & 0.49 \\
\hline
\end{tabular}

Signif. Codes: $0.1() .0.05\left(^{(}\right) 0.01\left(^{(*)} 0.001\left(^{(* *)}\right.\right.$.

Source: Capital IQ, author's own calculations.

Table 5. Verification of hypothesis 1 (one year before bonds issuance - three years after bonds issuance). Robust standard errors were used

\begin{tabular}{|c|c|c|c|c|c|}
\hline $\begin{array}{l}\text { One year "before" - } \\
\text { two years "after" }\end{array}$ & $\begin{array}{l}\text { Revenue/ } \\
\text { Assets }\end{array}$ & $\begin{array}{l}\text { EBITDA/ } \\
\text { Assets }\end{array}$ & $\begin{array}{l}\text { EBIT/ } \\
\text { Assets }\end{array}$ & RoA & RoE \\
\hline Intercept & 0.0062 & $0.22^{\star * \star}$ & $0.22^{\star \star \star}$ & $-0.14^{\star \star \star}$ & -0.041 \\
\hline Log(assets) & $-0.011^{\star}$ & $-0.019^{\star * \star}$ & $-0.026^{* * *}$ & $-0.018^{\star * *}$ & -0.0027 \\
\hline$\partial($ Leverage) & $-0.0005^{\star *}$ & -0.0003 & -0.0004 & -0.0006 & -0.0004 \\
\hline Sector O\&G & $0.023^{*}$ & $0.018^{\star}$ & 0.017 & $0.011^{\star}$ & -0.0027 \\
\hline Country USA & -0.006 & 0.003 & 0.001 & -0.004 & -0.003 \\
\hline Bond issue & $0.056^{\star *}$ & $0.084^{\star \star \star}$ & $0.076^{\star *}$ & -0.0031 & $0.192^{\star * *}$ \\
\hline Adjusted R sq & 0.42 & 0.53 & 0.50 & 0.34 & 0.46 \\
\hline
\end{tabular}

Signif. Codes: 0.1 (.) $0.05\left(^{(}\right) 0.01\left(^{* *}\right) 0.0011^{(* *)}$.

Source: Capital IQ, author's own calculations.

In Table 4, a change of performance indicators is studied for the period of one year before bonds issue and two years after the issue, in Table 5 - the period of one year before bonds issue and three years after the issue.

A study of two different periods described in Tables 6-7 helps not only to evaluate the influence of a bond issue on corporate performance, but also to define the dynamics of such influence: e.g. in how many years after a bond issue the peak effect is achieved.

In accordance with the achieved result, the bond issue has a statistically significant influence on almost all indicators of corporate performance both after two years and after three years since the date of a bond issue. All other things being equal, the positive effect of a bond issue influences EBITDA/Assets in three years by $26 \%$ more than its effect after two years. For example, all other things being equal, if a company issues bonds, EBITDA/Assets increases by 8 basis points in three years after the issue. However, it should be noted that the positive influence peak falls at the third year after the issue. This result may be related to the fact that the majority of investment projects have a long period of implementation. As such, the company may achieve the use of new capacities in full, accompanied by a corresponding growth of corporate performance indicators by the end of 
the period of the project implementation. Consequently, we do not reject hypothesis 1 . It is worth emphasising that the explanatory power of the models with the use of new performance indicators which we have described before is significantly greater than that of models $4(\mathrm{RoA})$ and 5 (RoE) in which the return on assets and return on equity are the dependent variables, respectively.

\section{Results of verification of hypothesis 2}

As expected, a greater amount of corporate assets is associated with a lower value of the corporate perfor- mance indicator (it is observed in all models). Meanwhile the statistical significance of change of the corporate financial leverage was not found in almost almost all modifications of regression models when $n=3$.

However, when $n=2$ the statistical significance is observed for models 1 (Revenue/Assets), 2 (EBITDA/ Assets), 4 (RoA), 5 (RoE), nevertheless, the signs of evaluation of coefficients are different. Consequently, one cannot assert for sure the directionality of influence of the change of financial leverage on company performance.

Table 6. Verification of hypothesis 2 (one year before bonds issuance - two years after bonds issuance). Robust standard errors were used

\begin{tabular}{|c|c|c|c|c|c|}
\hline $\begin{array}{l}\text { One year "before" - } \\
\text { two years "after" }\end{array}$ & $\begin{array}{l}\text { Revenue/ } \\
\text { Assets }\end{array}$ & $\begin{array}{l}\text { EBITDA/ } \\
\text { Assets }\end{array}$ & $\begin{array}{l}\text { EBIT/ } \\
\text { Assets }\end{array}$ & $\mathbf{R o A}$ & RoE \\
\hline Intercept & 0.005 & $0.16^{* * *}$ & -0.024 & $0.11^{* * *}$ & $-0.28^{\star}$ \\
\hline $\log$ (assets) & -0.002 & $-0.012^{\star * *}$ & -0.001 & $-0.014^{* * *}$ & 0.011 \\
\hline Leverage & $-0.0008^{\star}$ & $0.0005^{\star}$ & 0.0007 & 0.0005 & $0.004^{\star}$ \\
\hline Leverage sq & $3^{*} e-06$ & $-6^{\star} e-07^{\star}$ & $-2^{*} e-07$ & $-4^{\star} e-07^{\star}$ & $-4^{*} e-06^{*}$ \\
\hline$\partial($ Leverage $)$ & $-0.0004^{\star}$ & -0.0005 & -0.0011 & -0.0003 & $-0.004^{* * *}$ \\
\hline Sector O\&G & $0.019^{*}$ & $0.015^{\star}$ & 0.013 & $0.01^{\star}$ & -0.003 \\
\hline Country USA & -0.007 & 0.001 & 0.005 & -0.008 & 0.003 \\
\hline Bond issue & $0.045^{\star *}$ & $0.064^{\star *}$ & $0.035^{\star}$ & -0.028 & $0.12^{*}$ \\
\hline Adjusted R sq & 0.36 & 0.49 & 0.24 & 0.48 & 0.55 \\
\hline
\end{tabular}

Signif. Codes: 0.1 (.) $\left.0.05\left(^{*}\right) 0.01\left(^{* *}\right) 0.0011^{* * *}\right)$.

Source: Capital IQ, author's own calculations.

Table 7. Verification of hypothesis 2 (one year before bonds issuance - three years after bonds issuance). Robust standard errors were used

\begin{tabular}{|c|c|c|c|c|c|}
\hline $\begin{array}{l}\text { One year "before" - } \\
\text { two years "after" }\end{array}$ & $\begin{array}{l}\text { Revenue/ } \\
\text { Assets }\end{array}$ & $\begin{array}{l}\text { EBITDA/ } \\
\text { Assets }\end{array}$ & $\begin{array}{l}\text { EBIT/ } \\
\text { Assets }\end{array}$ & RoA & RoE \\
\hline Intercept & 0.013 & $0.21^{\star * *}$ & $0.24^{\star * *}$ & $-0.14^{\star * \star}$ & -0.023 \\
\hline Log(assets) & $-0.004^{\star}$ & $-0.03^{* * *}$ & $-0.05^{\star * *}$ & $-0.006^{* * *}$ & 0.043 \\
\hline Leverage & -0.0003 & $0.0004^{\star}$ & $0.0004^{*}$ & $0.0003^{\star}$ & $0.006^{* * *}$ \\
\hline Leverage sq & $3^{*} e-06$ & $-1^{*} e-06^{* *}$ & $-3^{*} e-06^{* *}$ & $-6^{\star} e-07^{\star}$ & $-3^{*} e-06^{* * *}$ \\
\hline$\partial$ (Leverage) & $-0.0005^{\star *}$ & 0.00011 & 0.0003 & -0.001 & $-0.007^{\star}$ \\
\hline Sector O\&G & 0.005 & $0.018^{* *}$ & 0.011 & $0.013^{\star}$ & -0.007 \\
\hline Country USA & -0.001 & $0.005^{\star}$ & 0.006 & -0.003 & 0.003 \\
\hline Bond issue & 0.069 & $0.076^{*}$ & $0.079^{* *}$ & -0.061 & $0.29 * * *$ \\
\hline Adjusted R sq & 0.32 & 0.53 & 0.48 & 0.36 & 0.44 \\
\hline
\end{tabular}

Signif. Codes: 0.1 (.) $0.05\left(^{*}\right) 0.01\left(^{* *}\right) 0.0011^{* * *}$.

Source: Capital IQ, author's own calculations. 
The results of testing hypothesis 2 are illustrated in Tables 6 and 7. The methodology of its verification is similar to the methodology used for hypothesis 1. In particular, two explicative variables - Leverage and Leverage sq are added to all models which illustrate the value of the financial leverage at the date of the bond issuance. In our opinion, the influence of financial leverage on the company effectiveness is described by a nonlinear method. As stated above, the trade-off theory contemplates existence of the optimal level of the financial leverage at which the maximum value of corporate performance is achieved. Consequently, in order to take this suggestion into consideration in the analysis, it is necessary to add the value of the square of the financial leverage as the explanatory variable in all regression models.

According to the test results, with both $n$ values the coefficients of the regressors Leverage and Leverage sq are significant. For example, the growth of the financial leverage value by 1 percentage point results in a growth of EBITDA/Assets by 0.6 percentage points in three years after the bond issue. Thus, the influence of the financial leverage value on corporate performance is nonlinear. The coefficient of the regressor of Leverage sq has the negative sign in all forms of regression models, and besides for the explanatory variable Leverage, it is positive. Consequently, it is indicative of the form of dependence of the corporate performance value on the financial leverage value in the form of an inverse parabola. This supports the trade-off theory, although hypothesis 2 is rejected because the relation between the indicators is nonlinear.

\section{Results of verification of hypothesis 3}

Finally, to verify hypothesis 3 we also added the dummy variable - Green bond - in the model which takes on a value of 1 if the issued bond is green and 0 otherwise.

In accordance with the obtained results of the regression analysis (Tables 8 and 9) the influence of the Green bond indicator on company effectiveness is significant at both values of $n$ ( 1 or 2 ). In particular, when green bonds are issued, EBITDA/Assets value grows by 7.3 basis points within three years after the issue. However, the economic significance is higher for $n=2$. It is indicative of the fact that at earlier stages following a green bond issue, the positive effect on corporate performance is greater. This result may be related to the fact that investment projects financed from the funds raised from green bonds issue have a relatively shorter investment period. Our conclusion is that hypothesis 3 is not rejected.

The evaluation of the coefficient of the regressor GB/Debt which designates the share of green bonds in the corporate debt level is statistically significant and has a positive sign. In other words, all other things being equal, when the share of green bonds increases by $10 \%$, the performance indicators grow between 1 and 3 basic points. This may be explained by lower rates for such type of borrowings in comparison to other debt instruments. Consequently, hypothesis 3.1 is not rejected.

Table 8. Verification of hypothesis 3 (one year before bonds issuance - two years after bonds issuance). Robust standard errors were used

\begin{tabular}{|c|c|c|c|c|c|}
\hline $\begin{array}{l}\text { One year "before" - } \\
\text { two years "after" }\end{array}$ & $\begin{array}{l}\text { Revenue/ } \\
\text { Assets }\end{array}$ & $\begin{array}{l}\text { EBITDA/ } \\
\text { Assets }\end{array}$ & $\begin{array}{l}\text { EBIT/ } \\
\text { Assets }\end{array}$ & $\mathbf{R o A}$ & RoE \\
\hline Intercept & -0.006 & $0.18^{\star * *}$ & -0.025 & $0.13^{* * *}$ & -0.16 \\
\hline Log(assets) & -0.003 & $-0.026^{\star * *}$ & -0.0021 & $-0.015^{\star * *}$ & 0.016 \\
\hline Leverage & $-0.0006^{\star}$ & 0.0002 & 0.0004 & 0.0002 & $0.0005^{\star}$ \\
\hline Leverage sq & $2^{\star} e-06^{*}$ & $-8^{\star} e-07$ & $-3^{\star} e-07$ & $-3^{\star} e-07^{\star}$ & $-4^{\star} e-06^{\star}$ \\
\hline$\partial($ Leverage $)$ & $-0.0004^{*}$ & -0.0003 & -0.0001 & -0.0002 & $-0.007^{\star * *}$ \\
\hline Sector O\&G & 0.007 & $0.021^{* *}$ & 0.013 & $0.017^{\star}$ & 0.004 \\
\hline Country USA & -0.003 & 0.002 & 0.005 & -0.006 & -0.002 \\
\hline Bond issue & $0.042^{*}$ & $0.068^{\star * *}$ & $0.049^{*}$ & $-0.022^{* * *}$ & $0.16^{*}$ \\
\hline Green bond & $0.037^{\star}$ & $0.56^{* * *}$ & -0.025 & $0.05^{\star}$ & $0.33^{* *}$ \\
\hline GB/Debt & 0.002 & $0.003^{*}$ & $0.0017^{\star}$ & $0.0013^{\star}$ & 0.0006 \\
\hline Adjusted R sq & 0.38 & 0.47 & 0.29 & 0.48 & 0.49 \\
\hline
\end{tabular}

Signif. Codes: 0.1 (.) $\left.0.05\left(^{*}\right) 0.01\left(^{* *}\right) 0.0011^{* * *}\right)$.

Source: Capital IQ, author's own calculations. 
Table 9. Verification of hypothesis 3 (one year before bonds issuance - three years after bonds issuance). Robust standard errors were used

\begin{tabular}{|c|c|c|c|c|c|}
\hline $\begin{array}{l}\text { One year "before" - } \\
\text { two years "after" }\end{array}$ & $\begin{array}{l}\text { Revenue/ } \\
\text { Assets }\end{array}$ & $\begin{array}{l}\text { EBITDA/ } \\
\text { Assets }\end{array}$ & $\begin{array}{l}\text { EBIT/ } \\
\text { Assets }\end{array}$ & RoA & RoE \\
\hline Intercept & 0.012 & $0.22^{* * *}$ & $0.21^{\star * *}$ & $0.14^{\star * *}$ & -0.039 \\
\hline $\log ($ assets $)$ & $-0.006^{*}$ & $-0.029^{* * *}$ & $-0.037^{* * *}$ & $-0.012^{* * *}$ & 0.018 \\
\hline Leverage & -0.0003 & $0.0002^{*}$ & $0.0003^{\star}$ & $0.0003^{*}$ & $0.007^{* *}$ \\
\hline Leverage sq & $3^{*} e-06^{*}$ & $-4^{*} \mathrm{e}-06$ & $-7^{\star} e-06$ & $-3^{*} \mathrm{e}-07$ & $-3^{*} e-06^{* * *}$ \\
\hline$\partial$ (Leverage) & $-0.0004^{* *}$ & $0.0006^{*}$ & 0.0004 & -0.0004 & $-0.0016^{*}$ \\
\hline Sector O\&G & 0.008 & $0.025^{\star}$ & $0.015^{\star}$ & 0.012 & 0.007 \\
\hline Country USA & -0.004 & 0.0018 & $0.002^{*}$ & -0.002 & -0.001 \\
\hline Bond issue & $0.062^{* *}$ & $0.071^{\star *}$ & $0.075^{\star *}$ & -0.001 & $0.25^{* * *}$ \\
\hline Green bond & 0.22 & $0.37^{\star}$ & $0.35^{\star}$ & -0.08 & $0.11^{*}$ \\
\hline GB/Debt & 0.005 & $0.0031^{\star}$ & $0.0029^{*}$ & $0.0021 *$ & 0.003 \\
\hline Adjusted R sq & 0.37 & 0.51 & 0.49 & 0.43 & 0.45 \\
\hline
\end{tabular}

Signif. Codes: 0.1 (.) $0.05(*) 0.01(* *) 0.001(* * *)$.

Source: Capital IQ, author's own calculations.

\section{Conclusion}

In this article, we evaluated the influence of the debt level on corporate performance in various economic sectors where both green bonds and regular bonds were issued. We can make the following conclusions.

Hypothesis 1: Bonds issuance has a positive effect on corporate performance.

The bond issuance shows a positive influence on almost all corporate performance indicators both after two years and after three years following the date of the bond issuance. The positive effect of the bond issue for EBITDA/ Assets is greater after three years than after two years. For example, all other things being equal, if a company issues bonds, EBITDA/Assets increases by 8 basic points in three years after the issue. The positive influence peak falls at the third year after the issue. This is related to the fact that, as a rule, bonds issues show their effect over the long term, sometimes in three years or more. Thus, in longer periods the corporate performance seems to increase.

Hypothesis 2: The interrelation between the debt level and corporate performance is described by means of a nonlinear function.

Growth of the financial leverage indicator by 1 percentage point results in a growth of EBITDA/Assets by 0.6 percentage points in three years after the bond issue. Consequently, when the debt level grows, the corporate performance increases by $0.6 \%$ in the time horizon of three years. The coefficient of the regressor of Leverage sq has the negative sign in all forms of regression models, and except for the explanatory variable Leverage it is positive. Consequently, it is indicative of the form of dependence of the corporate performance indicator on the financial leverage value in the form of an inverse parabola.
Hypothesis 3: Issuance of green bonds has a greater positive effect on corporate performance than the issuance of straight bonds.

When green bonds are issued, EBITDA/Assets value grows by 7.3 basis points in three years after the bond issue. However, the economic significance is higher for a two-year period after the issue of a green bond. It is indicative of the fact that at earlier stages after a green bond issue, the positive effect on corporate performance is greater because green bonds produce effects in a shorter term than straight bonds.

Hypothesis 3.1: Growth of the share of green bonds in the amount of the company debt has a positive impact on corporate performance.

All other things being equal, when the share of green bonds increases by $10 \%$ the performance indicators grow between 1-3 basis points. We considered several financial performance indicators, where each of them has its advantages and drawbacks. Nevertheless, the choice of specification of the performance indicators has not resulted in significant changes in the research results. It should be noted that performance of the companies which issue bonds, all other things being equal, exceeds performance of the companies which issue straight bonds. One of the most attractive potential lines of future research is to study the influence of green bonds issuance on corporate performance at various life cycles of company development. At the present stage of development of the green bonds market it is impossible to study their influence on corporate performance because the research selection is rather small, and this market has emerged rather recently. For further studies it would be interesting to analyse the influence of green bonds issuance by companies in various countries and economic sectors on their corporate performance. 


\section{Appendixes}

\section{Appendix 1. Models Testing}

\section{Models Testing}

\begin{tabular}{|c|c|}
\hline & $\begin{array}{l}\text { Model Revenue/Assets } \\
\text { (Table 10) }\end{array}$ \\
\hline Test statistics & Evaluation \\
\hline \multicolumn{2}{|c|}{$\mathrm{H}_{0}$ : errors homoscedasticity } \\
\hline White test & 42.74 \\
\hline P-value & 0.00 \\
\hline Conclusion & $\mathrm{H}_{0}$ is not rejected \\
\hline Breusch-Pagan test & 7.0557 \\
\hline P-value & 0.03 \\
\hline Conclusion & $\mathrm{H}_{0}$ is not rejected \\
\hline \multicolumn{2}{|c|}{$\mathrm{H}_{0}:$ Absence of errors autocorrelation } \\
\hline Durbin-Watson test & 1.6 \\
\hline Conclusion & $\mathrm{H}_{0}$ is not rejected \\
\hline \multicolumn{2}{|c|}{$\mathrm{H}_{0}$ : Absence of significant multicollinearity } \\
\hline Mean value of VIF & 1.31 \\
\hline Maximum VIF & 2.47 \\
\hline Conclusion & $\mathrm{H}_{0}$ is not rejected \\
\hline \multicolumn{2}{|c|}{$\mathrm{H}_{0}$ : The model is adequately specified } \\
\hline Ramsey test & 0.69 \\
\hline P-value & 0.50 \\
\hline Conclusion & $\mathrm{H}_{0}$ is not rejected \\
\hline \multicolumn{2}{|l|}{$\mathrm{H}_{0}:$ No endogeneity } \\
\hline Endogeneity: & $\operatorname{Cov}\left(\vec{X}_{t} ; \varepsilon_{t}\right)=0$ \\
\hline $\operatorname{Cov}\left(\vec{X}_{t} ; \varepsilon_{t}\right)$ & $\sim 0$ \\
\hline Conclusion & $\mathrm{H}_{0}$ is not rejected \\
\hline
\end{tabular}


The regression models were verified for adequacy in several stages. At each stage, certain characteristic features of the models were verified, and in case of unsatisfactory results, certain actions were performed in order to improve the quality of the regression models considered in the paper. Below we describe the course of actions performed to verify the models.

The first stage of the verification implies study of characteristics of the remains of regression models for the existence of the heteroscedasticity problem. Among the consequences of existence of this characteristic are inefficient evaluations of coefficients and distortions of prerequisites for the use of t-statistics. In order to check this characteristic feature, we applied two tests: the White test and the Breusch-Pagan test. The zero hypothesis contemplates an absence of the heteroscedasticity problem. If the p-value exceeds a $5 \%$ level, the zero hypothesis is rejected, and it is indicative of the presence of the heteroscedasticity problem. In order to solve this problem we used the standard errors justifiable for heteroscedasticity.

The next stage implies verification for errors autocorrelation. In particular, we applied the Durbin-Watson test, the zero hypothesis for which contemplates an absence of errors autocorrelation. The zero hypothesis was not rejected in our models.

At the third stage, we verified the existence of the multicollinearity problem in the data. For this purpose, we used the variance inflation factor (VIF) which was less than 5 for all regressors in the models, and this is an indirect proof of absence of the multicollinearity problem.

We used the Ramsey test to verify the adequacy of the model's specification. The zero hypothesis states that all coefficients preceding regressors equal zero. In a similar way, the zero hypothesis of the Ramsey test is rejected for all models.

In order to solve the endogeneity problem, the instrumental variables method was used when necessary.

\section{References}

1. Agliardi E. How can we "Take urgent action to combat climate change and its impact" (UN SDG N. 13) under ambiguity aversion? European Journal of Sustainable Development Research. 2018;2(2):21. DOI: $10.20897 /$ ejosdr/85339

2. ESG factors in investing. PwC. 2019. URL: https://www.pwc.ru/ru/sustainability/assets/pwcresponsible-investment.pdf (In Russ.).

3. 2019 Green bond market summary. Climate Bonds Initiatives. Feb. 2020. URL: https://www. climatebonds.net/system/tdf/reports/2019_annual_ highlights-final.pdf?file $=1 \&$ type $=$ node $\& i d=46731 \& f$ orce $=0$

4. Popova S., Karlova N., Ponomarenko A., Deryugina E. Analysis of the debt burden in the sectors of the Russian economy. Bank of Russia.
Economic Research Report Series. 2018;(29). URL: https://publications.hse.ru/mirror/pubs/share/ direct/229577174.pdf (In Russ.).

5. Jensen M.C., Meckling W.H. Theory of the firm: Managerial behavior, agency costs, and ownership structure. Journal of Financial Economics. 1976;3(4):305-360. DOI: $10.1016 / 0304-405 \mathrm{X}(76) 90026-\mathrm{X}$

6. Dybvig P.H., Ross S.A. Arbitrage, state prices and portfolio theory. In: Constantinides G.M., Harris M., Stulz R.M., eds. Handbook of the economics of finance. 2003;1(Pt. B):605-637.

7. Harris M., Raviv A. Capital structure and the informational role of debt. The Journal of Finance. 1990;45(2):321-349. DOI: 10.1111/j.1540-6261.1990. tb03693.x

8. Vijayakumaran R., Vijayakumaran S. Leverage, debt maturity and corporate performance: Evidence from Chinese listed companies. Asian Economic and Financial Review. 2019;9(4):491-506. DOI: 10.18488/ journal.aefr.2019.94.491.506

9. Abor J. The effect of capital structure on profitability: An empirical analysis of listed firms in Ghana. Journal of Risk Finance. 2005;6(5):438-445. DOI: $10.1108 / 15265940510633505$

10. Vijayakumaran R. Capital structure decisions, agency conflicts and corporate performance: Evidence from Sri Lankan listed manufacturing firms. International Journal of Accounting \& Business Finance. 2015;1(1):1-14. URL: http://www.maco. jfn.ac.lk/ijabf/wp-content/uploads/2017/11/vol1_ issue1_1.pdf

11. Flammer C. Does corporate social responsibility lead to superior financial performance? A regression discontinuity approach. Management Science. 2015;61(11):2549-2568. DOI: 10.1287/ mnsc. 2014.2038

12. Hart S.L., Ahuja G. Does it pay to be green? An empirical examination of the relationship between emission reduction and firm performance. Business Strategy and the Environment. 1996;5(1):30-37. DOI: 10.1002/(SICI)1099-0836(199603)5:1<30::AIDBSE38>3.0.CO;2-Q

13. Christmann P. Multinational companies and the natural environment: Determinants of global environmental policy. The Academy of Management Journal. 2004;47(5):747-760. DOI: 10.5465/20159616

14. Darnall N., Jolley G.J., Ytterhus B. Understanding the relationship between a facility's environmental and financial performance. In: Johnstone N., ed. Environmental policy and corporate behaviour. Cheltenham: Edward Elgar Publishing Ltd.; 2007:213-259. 
15. Bansal P. Evolving sustainably: A longitudinal study of corporate sustainable development. Strategic Management Journal. 2005;26(3):197-218. DOI: 10.1002/smj.441

16. Della Croce R., Kaminker C., Stewart F. The role of pension funds in financing green growth initiatives. OECD Working Papers on Finance, Insurance and Private Pensions. 2011;(10). URL: http://www.oecd. org/finance/private-pensions/49016671.pdf

17. Zerbib O.D. Is there a green bond premium? The yield differential between green and conventional bonds. SSRN Electronic Journal. 2016:2889690. DOI: $10.2139 /$ ssrn. 2889690

18. Agliardi E., Agliardi R. Financing environmentallysustainable projects with green bonds. Environment and Development Economics. 2019;24(6):608-623. DOI: $10.1017 /$ S1355770X19000020

19. Strebulaev I.A. Do tests of capital structure theory mean what they say? The Journal of Finance. 2007;62(4.):1747-1787. DOI: 10.1111/j.15406261.2007.01256.x

20. Myers S.C., Majluf N.S. Corporate financing and investment decisions when firms have information that investors do not have. Journal of Financial Economics. 1984;13(2):187-221. DOI: 10.1016/0304405X(84)90023-0

21. Baskin J. An empirical investigation of the pecking order hypothesis. Financial Management. 1989;18(1):26-35. DOI: 10.2307/3665695

22. Calomiris C.W., Hubbard R.G. Internal finance and investment: Evidence from the undistributed profits tax of 1936-1937. NBER Working Paper. 1993;(4288). URL: https://www.nber.org/papers/w4288.pdf

23. Datta D.K., Guthrie J.P., Wright P.M. Human resource management and labor productivity: Does industry matter? The Academy of Management Journal. 2005;48(1):135-145. DOI: 10.2307/20159645

24. Pagano M., Volpin P.F. Managers, workers, and corporate control. The Journal of Finance. 2005;60(2):841-868. DOI: 10.1111/j.15406261.2005.00748.x

25. Mina A., Lahr H., Hughes A. The demand and supply of external finance for innovative firms. Industrial and Corporate Change. 2013;22(4):869-901. DOI: 10.1093/icc/dtt020

26. Tian L., Estrin S. Debt financing, soft budget constraints, and government ownership: Evidence from China. Economics of Transition. 2007;15(3):461481. DOI: 10.1111/j.1468-0351.2007.00292.x
27. King A.A., Lenox M.J. Does it really pay to be green? An empirical study of firm environmental and financial performance. Journal of Industrial Ecology. 2001;5(1):105-116. DOI: $10.1162 / 108819801753358526$

28. Lassala C., Apetrei A., Sapena J. Sustainability matter and financial performance of companies. Sustainability. 2017;9(9):1498. DOI: 10.3390/ su9091498

29. Miroshnychenko I., Barontini R., Testa F. Green practices and financial performance: A global outlook. Journal of Cleaner Production. 2017;147:340351. DOI: 10.1016/j.jclepro.2017.01.058

30. Aguilera-Caracuel J., Ortiz-de-Mandojana N. Green innovation and financial performance: An institutional approach. Organization \& Environment. 2013;26(4):365-385. DOI: $10.1177 / 1086026613507931$

31. Van der Laan G., Van Ees H., Van Witteloostuijn A. Corporate social and financial performance: An extended stakeholder theory, and empirical test with accounting measures. Journal of Business Ethics. 2008;79(3):299-310. DOI: 10.1007/s10551-007-93980 